\title{
Do You Know Me? E Mohio Ana Koe Ki Ahau?
}

\section{A resource for educators}

\section{Bill Gilmore}

Psychologist, Ministry of Education, Special Education, Otago

Vicky Haslam

Service Manager, Ministry of Education, Special Education, Waikato

Raewyn Hitaua

Early Intervention Teacher, Ministry of Education, Special Education, Gisborne.

Bruce Kent

Senior Advisor, Professional Practice and Psychologist, Ministry of Education, Special Education, Manukau

Esther Tavui

Adviser on Deaf Children, Ministry of Education, Special Education, Auckland City

Alison Tu'ionetoa

Special Education Advisor, Pasifika Liaison, Ministry of Education, North West District

Margaret Crosswell

Early Intervention Teacher, Ministry of Education, Special Education, Otago

\begin{abstract}
The article shares some of the reflections of the project team who developed the Do You Know Me? E Mohio Ana Koe Ki Ahau? resource for educators, which aims to assist educators in both school and early childhood education services to clarify concerns about young children and take appropriate action. Issues discussed include the context and origins for the project, contrasting models of screening, the importance of relationships and community concern, inclusion, the implications of language, social realities, diversity, and the reflective practice model.
\end{abstract}

\section{Practice Paper \\ Keywords}

Early childhood education, effective practice, early intervention, learning difficulties, parent school relationship, reflection, teacher development, vulnerable children, young children.

\section{BACKGROUND}

The purpose of this article is to share some of the learning and reflections from the Better Information to Address Barriers to Learning project, which led to the development of the Do You Know Me? E Mohio Ana Koe Ki Ahau? resource at three trial sites in 2006. The title was informed by the learning stories approach as indicated in Kei Tua o te Pae Assessment for Learning: Early childhood exemplars (Ministry of Education, 2004a), the work of Carr, May and Podmore regarding "the child's questions" (Carr, May \& Podmore, 2000; Podmore, 2003; Podmore \& May, 1998; Podmore, May $\&$ Carr, 2001), and by the responses of project participants during the development of the resource.
There is ongoing concern in New Zealand about children who for one reason or another are seen as "falling through the gaps". A number of current government initiatives are aimed at identifying and meeting the needs of vulnerable children, including the development by the Ministry of Health of a new "Well Child" health check aimed at four to five year old children (Ministry of Health, 2007) and a suite of initiatives by the Ministry of Social Development aimed at intervening early in the lives of vulnerable children (Ministry of Social Development, 2007). Current Ministry of Education concern lies in effective teaching, including responding flexibly and appropriately to the needs of learners, engaging effectively with parents and whānau', and in supporting quality providers, for instance, by providing appropriate assessment resources and encouraging the sharing of best practice and innovation (Ministry of Education, 2006). One of the ways in which the Ministry of Education has begun to address this issue is through the Better Information to Address Barriers to Learning project (BITABL). The original project acknowledged that new knowledge was needed about how we could best support schools, early childhood services, social services, specialists, and families to overcome barriers to children's learning. In particular, we needed to ensure its suitability for Māori, Pasifika and rural children.

The project team has designed a draft resource to assist educators of young children to gain better information to clarify possible concerns, to encourage discussion and to take solution-focused action. A group of site facilitators from within Ministry of Education, Special Education worked with local schools and early childhood education services (ECES) in three geographical areas to design and gain feedback about 
the resource. The development process included initial work to clarify the parameters of the project, work with educators and other community members in each site to gain commitment to the development process, research and writing of the resource, and several cycles of sharing, trial of the resource, feedback gathering and resource revision. The resource grew and changed considerably over the course of this development.

Recently the draft resource material has been placed in an online environment to continue the development of the resource and to support the continuing application at trial sites. The project has been shaped by policy decisions, a literature review, a national advisory group, and a steering group, as well as by independent evaluation. This article shares some of what the project team learned and thought about during this journey.

\section{REFLECTIONS}

\section{"Screening" or Holistic Community Concern}

The concept of universal screening was an important contributing influence to the project. Discussion early in this project focused on whether it could be applied to New Zealand educational settings. There are many potential variations on the theme of screening programmes. Many screening programmes come from medical models, and apply a screening tool to a particular population in an effort to detect and potentially ameliorate specific conditions. A literature review was commissioned to assist the project and noted that New Zealand does not, as a matter of course, screen children for learning or developmental delays within early childhood education or school settings. It found that a number of tools and processes are used intermittently throughout the country. It also concluded that there is significant variation in the tools and processes used internationally. No single tool is recommended or used above all others' (Fieldsend \& Carter, 2005, p. 7).

Although there seems little doubt that recognising children's needs early across a wide variety of developmental domains and across children's contexts for learning, can potentially be helpful in preventing the development of more serious difficulties affecting children's learning (Albers, Glover \& Kratochwill, 2007; Elliott, Huai, \& Roach, 2007; Seversen, Walker, Hope-Doolittle, Kratochwill \& Gresham, 2007; Whitely, Smith, \& Hutchinson, 2005) the concept of universal screening draws considerable adverse comment. One demonstration of this was the local reaction reported in the media to the suggestions of the Commissioner for Children, who advocated for regular "checks" on children, based on a Scottish pilot model (Checks on Children Slammed, 2006). One reason for such a reaction within education may be a feeling that "screening" may not adequately address the complexity of social, whānau, and individual factors that impact on children's learning. Concepts of universal screening may also not have a good philosophical "fit" with holistic and strength-based models of practice. The project team concluded that within education in New Zealand "screening" does not appear to be a particularly productive way of describing or encouraging a community's concern for its children within education, although it may be very useful for certain specific conditions.

The project stopped using the term "screening" because of its multiple value-laden meanings. Instead, across the three sites themes emerged from discussions and trial of the resource material that are also consistent with existing literature on effective practice in education. These themes were shared in all sites but with different emphases in different contexts. The themes included:

- partnerships between home and teachers

- engaging a community of learning (including parents, teachers, and wider communities)

- professional learning that encourages pedagogical and knowledge development, collaborative enquiry and reflective practice.

The concept of community - community of concern and community of practice (Buysse, Sparkman \& Wesley, 2003; Jones, 2006; Wenger 1998, 2002) - seemed very applicable to this project. Our project team was particularly informed by discussions about the importance of connecting and sharing information with the diverse communities that make up Pasifika in Auckland, the kaupapa ${ }^{2}$ of whanaungatanga ${ }^{3}$ from the community in the Gisborne area, and the discussion of parent/school/ECES relationships in Otago.

A community can be empowered to reflect on its children and take action to address barriers to their learning. Providing a resource that can assist the educators who are part of the community to better connect with parents and whānau, clarify concerns and take action is one way to help educators work proactively for their children. If educators and communities can contribute to the development of the resource, they may have greater ownership of it and its implementation. Perhaps the most significant outcome of the project so far has been the constructive work with the local educators from the three sites to develop the resource; as Pollard and James (2006) put it, to explore effective use of mediating tools and artefacts to support collaborative dialogue. In plainer terms, the development of the resource provided a focus to draw people together to think about and act on these issues.

The process of discussing and developing the resource has been valuable in itself. It is a definite asset that the resource remains in a "draft" state, and now has an online community around it to promote such discussion and further development. As such, it continues to invite active and respectful engagement with the communities, partnerships between home and school, and intentional professional learning.

The current understanding of effective educators' professional development (in that it nurtures communities that co-construct learning and enhances pedagogical practice) suggests that uncritical implementation of procedures is not likely to be productive. Rather, what is needed is 'an active generative process that entails teachers making change at various levels' (Mitchell \& Cubey, 2003, p. 91). Required and uncritical implementation of procedures

2 Philosophy

3 Relationships 
is not consistent with a context specific, situated approach to professional development (Guskey, 2002) nor with the collaboration involved in professional inquiry that examines practice and seeks information (Robertson, 2005). This resource, therefore, aimed to support the process of guided teacher enquiry.

\section{Language and Inclusion}

The project team members were very concerned that the resource should contribute to inclusive teaching practice. We were aware of the potential for a resource that seeks to identify and address barriers to actually create barriers through a focus on individual pathology and deficit. Language use seemed a crucial part of this and discussion of the language assisted in clarifying many of the issues involved in the project. We discovered that language used reflects underlying, often unspoken beliefs and world views. As the project literature review commented for example, the term "barriers" connotes a fixed variable rather than recognising that detrimental influences can be mitigated and addressed' (Fieldsend \& Carter, 2005, p. 5). Consideration of the term also suggested discussions about context, and about deficit-based versus strength-based approaches.

Language use can also be influential by what it includes or omits. We were very interested (and at times confused) by the wide variety of terms used in literature in the fields of education, psychology, social welfare and health such as "risk factors", "variables" and "influences". Children are talked about as "vulnerable", "at risk", and "deprived". Their needs are "severe", "moderate", and "mild" or "marginal". They can be "diverse", "resilient", or have "needs". They follow "developmental pathways" toward statistically-predicted outcomes. Often language used seems individualistic and decontextualises the child's development whereas 'the creation of inclusive school communities ... necessitates ongoing, coordinated, systematic efforts to involve parents' (Gorinski, 2005, p. 7). This is particularly relevant in the NZ context where "Māori human development is embodied in "te ira tangata" '(the principle of people)' (Royal Tangaere, 1996, p. 11).

Language is important, and though we often didn't fully realise what was happening at the time, it has often caused us to pause while we considered what we and others were actually saying during the project. As Ballard (2004) points out 'language is how we name the world and assign cultural meanings to who we are and what we do' (p. 96). He suggests that 'a concern for "children" [rather than "learners", or in our view many of the other labels we read] would seem to evoke the teacher as professional but also as a member of a community concerned for its children' (p. 100).

Other discussion points around language for the project revolved around the audience and name for the resource. We deliberately chose the word "educators" in the wider meaning of the word, which potentially encompasses teachers, parents and whānau, or others involved with the child. The name of the resource also seemed of great significance in trying to capture at least some of the key elements within it. Do You Know Me? was a question presented previously in work around assessment and evaluation in early childhood and linked to the belonging strand of Te Whăriki, the early childhood curriculum (Carr, et al., 2000; Podmore et al, 2001; Podmore \& May,1998; Podmore, 2003). This question seemed to the participants to succinctly suggest the child's perspective and the holistic, reflective focus of the resource, and met with widespread approval. As one principal said, "Do You Know Me? - it's perfect really."

\section{Developing Reciprocal and Responsive Relationships} Jones (2006) highlights the necessity of developing reciprocal and responsive relationships between the family and the centre or classroom teacher, because families possess resources of skills and knowledge that educators can tap into, but also because the family is a mediating factor in terms of the child's interactions with the various learning communities the child is involved in.

The family can be seen as a pivotal point and constant frame of reference for the child. At any one time a child is a participant in many communities, not just one. It is the family as the mediating factor that has the knowledge of the child's experience of these things. (Jones, 2006, p 30)

From a family resilience perspective, 'each interaction between home and school is an opportunity to strengthen a family's capacity to overcome adversity and successfully rear its children' (Amatea, Smith-Adcock, \& Villares, 2006, p. 181). The Harvard Family Research Project (2007) suggests that educators need to create mechanisms for continuous family involvement from early childhood to school. They suggest that recent initiatives underscore the importance of coconstruction, which refers to the idea that 'home-school relationships are defined by reciprocal activities and trust' including engaging in dialogue with families (Harvard Family Research Project, 2007, p. 8).

During this project the project team learned about some of the challenges involved in the process of engaging families; about teachers feeling that they needed to "drag the parents in from the school gate", about busy parents being less able or willing to be involved with their children's early childhood centre, about differing perspectives about the child between home and education, and about cultural factors that impact on this involvement. Teachers described positive communication, but also acknowledged time pressures and challenges. However, we also learned about the immense value of involving family from stories as told by parents and educators involved in the project. For example, in one moving story from a Pasifika family, teachers' initial concerns about a little girl showing emotional and behavioural difficulties which were affecting her learning appeared to revolve around perceptions of abuse. However, by using the process of family consultation suggested in the Do You Know $M e$ ? resource, the child's issues and background were discussed with the family, additional help was sought, the concerns were reframed as attachment issues, and this little girl's learning situation improved significantly. More than that, a basis for trust and ongoing family involvement with the school was formed. 


\section{Relationship to Other Sectors}

Educators can play a key role in each child's development. Education is, however, only one aspect of provision for children's wellbeing. A recent New Zealand health summit (Canterbury District Health Board, 2007) devoted to the health needs of the under fives clearly demonstrated both the disparity that exists in New Zealand and the wide range of positive responses the community is making to these needs. Just where a project like BITABL might fit was another key issue, but an important one to clarify because without defining the role the task can appear overwhelming.

There are boundary issues for educators in a process that attempts to address barriers to children's presence, participation and learning. One good example of this was highlighted when a few of those involved in the project (educators and facilitators) initially identified poverty as a barrier to learning. Perhaps this was because we felt helpless in addressing such an issue, although there are actually many ways that schools and early childhood services can assist children to overcome disadvantage through innovative practices (Black, 2006). In the draft resource, questions about living context are included to encourage at least some reflection on this issue. Child abuse is another issue that educators may confront, but which can also cause dilemmas (Walsh, 2006). Sections on abuse are included in the resource in order to facilitate educators urgently addressing this issue when it arises.

\section{Diversity}

Phase one of the project was situated at three widely disparate communities: a predominantly Pasifika school and community in South Auckland; a group of largely Māori Kura and Kohanga Reo near Gisborne; and an Otago semirural cluster of mostly New Zealand European children. Other examples of diversity included cultural diversity, socioeconomic diversity, geographical diversity, and diversity not only between the early childhood and school education sectors, but also within these sectors. Exposure to this diversity was a key learning. In theoretical terms, we knew about the wide variety of communities in New Zealand. The reality, however, is that educators often work within a restricted area. This diversity did point out to us the challenges of producing a resource that was able to be relevant to the wide range of New Zealand communities. The sharing educators did with each other during the project also showed the value of educators being exposed to a variety of experiences.

Differences between the early childhood sector, owning and indeed highly valuing the early childhood curriculum $T e$ Whāriki (Ministry of Education, 1996) which is firmly based in a sociocultural perspective, and the school sector, which can appear more achievement- and competence-oriented, presented both a barrier and an opportunity. Transition to school was mentioned on a number of occasions as a key issue. Early on in the project, it seemed helpful to design a resource that would be appropriate across diverse settings, such as early childhood and school. The resource consequently had the potential through discussion and use, to bring people and communities together, rather than perpetuate barriers between groups. One potential way we saw to bridge the ECES/school gap was to use the concept of learning dispositions, which provides a useful alternative framework to learning competencies and may provide a common focus between early childhood and school educators. Others have begun to see this as a potential meeting place for educators (Carr, 2006). Consequently, learning dispositions frame a section in the resource designed to help educators reflect on their teaching practice and provision for the child. Feedback from some early childhood educators was very positive about this but it seemed that often educators would need time to learn about this concept and to see whether it might provide a helpful framework for them.

\section{Realities}

At times, we were presented with a strong message that the social realities of local communities needed to be understood and taken into account in a project such as this. Urgent needs in some communities were brought home to us particularly by our project members and contacts from Pasifika and Māori communities. Other reading (Centre for Community Child Health, 2007, Sykora, 2005, Wilms, 2002) and experiences with the project pointed out that vulnerable children do exist in every community, although these needs may lie in different areas for different communities.

An issue that was presented to us by some of the educators concerned resource and service availability. Educators can be strong advocates for their children. Sometimes they saw gaps in resource or service provision and asked the question "if we identify issues, but there are no services available to address these issues, then what happens?" We do believe that the resource, and work that might be associated with it, could potentially play a part in addressing this issue in a number of ways. Examples include: adding to educators' knowledge and skills; helping them to have good processes in place; enabling referrals to services to be better informed and more comprehensive; helping educators to collaborate with parents and caregivers to address issues in new ways, and highlighting areas of need more clearly so that policy and provision can be adjusted.

At the beginning, the project was influenced by knowing that simply asking questions unearths needs. The Pediatric Evaluation of Developmental Status (Glascoe, 2003; American Academy of Pediatrics, 2001; Centre for Community Child Health, 2007) implemented in communities in the United States of America and Australia, demonstrated that simply asking parents the question "Do you have any concerns about your child?" across a variety of developmental domains, facilitates parents in expressing concerns and leads to increased identification of developmental needs. A pilot project, Seeds for Success (Gilmore et al., 2004), demonstrated that asking teachers to reflect in a structured way on the behavioural needs of their five-year-old children led to children being identified and receiving services from Resource Teachers: Learning and Behaviour that they probably would not have received at that time otherwise. International initiatives such as the Australian Early Development Index have shown that exploring the developmental needs of a community's children proactively can help communities begin to address these needs more adequately (Centre for Community Child Health, 2006). 


\section{Reflective teaching}

Florian (2006) states 'difficulties in learning can be reconceptualised as dilemmas for teaching. In this way difficulties in learning are not problems within learners but problems for teachers to solve' (p. 26). Whilst being proactive, rather than using a "wait to fail" model (Elliot, et al., 2007) can cause potential demands on resource and service provision, we believe it also allows educators and communities to find new ways to address the needs of their children, and fits well with the paradigm of reflective teaching. Reflective practice involves open minded consideration of alternative views and understandings, and then examining ways that these can be applied to practice. Educators we consulted were comfortable with the concept of the reflective practitioner, and demonstrated reflection during the project development. The resource adopted this model as the proactive starting point for consideration of children's needs, for making changes that help the environment to better fit the child, and for placing teachers as key members of communities concerned about children.

\section{REFERENCES}

Albers, C., Glover, T., \& Kratochwill, T. (2007). Where are we at now? Journal of School Psychology 45, 257-263.

American Academy of Pediatrics. (2001). Developmental surveillance and screening of infants and young children. Pediatrics 108(1), 192-196.

Amatea, E., Smith-Adcock, S., \& Villares, E. (2006). From family deficit to family strength: Viewing families contributions to children's learning from a family resilience perspective. Professional School Counselling, 9(3), 177-188

Ballard, K. (2004). Learners and outcomes: Where did all the children go? New Zealand Journal of Teachers' Work, 1(2), 95-103.

Black, R. (2006). Overcoming disadvantage through the innovative classroom. Paper presented at the Australian Association for Research in Education 2006 Conference. Retrieved April 16, 2007, from http://www. educationfoundation.org.au/downloads/Rosalyn\%20Blac k\%20AARE\%20Conference\%202006.pdf

Buysse, V., Sparkman, K., \& Wesley, P. (2003). Communities of practice: Connecting what we know with what we do. Exceptional Children, 69(3), 263-277.

Canterbury District Health Board. (2007). Child Health Summit. Retrieved April 16, 2007, from http://www. cpublichealth.co.nz/Projects/Child-Health-Summit.asp

Carr, M. (2006). Learning dispositions and key competencies: A new curriculum continuity across the sectors? set: Research Information for Teachers, 2, 23-27.

Carr, M., May, H., \& Podmore, V. N. (with Cubey, P., Hatherly, A. \& Macartney, B. 2000). Learning and teaching stories: Action research on evaluation in early childhood. Wellington, New Zealand: New Zealand Council for Educational Research.
Centre for Community Child Health. (2007). Royal Children's Hospital, Melbourne. Australian Early Development Index. Retrieved April 16, 2007, from http://www.rch.org. au/australianedi

Centre for Community Child Health, Royal Children's Hospital Melbourne. (2007). Parents' Evaluation of Developmental Status (PEDS). Retrieved April 16, 2007 from http://www. rch.org.au/ccch/pub/index.cfm?doc_id=6472

Checks on Children Slammed. (2006, 25 January). New Zealand Herald. Retrieved April 16, 2007 from http://www.nzherald.co.nz/organisation/story.cfm?o_ id $=402 \& 0$ bjectID $=10365319$

Elliott, S., Huai, N. \& Roach, A. (2007). Universal and early screening for educational difficulties: Current and future approaches. Journal of School Psychology, 45, 137-161.

Fieldsend, A., \& Carter, A. (2005). Better information to address barriers to learning: Literature review and stocktake. Final report to Ministry of Education. Wellington, New Zealand: Allen \& Clarke Policy and Regulatory Specialists.

Florian, L. (2006). Teaching strategies: For some or all? Kairaranga, 7, Special Issue, 24-27

Gilmore, B., Laurie, D., Brown R., Van Midden, N., MeadMcKewan, L., Bretherton, M., Broere, C., Buxton, J., \& Hutchings, A. (2004). Seeds for Success: He Kakano ka puawai. School entry behaviour screening and intervention. Kairaranga, 5(2) 28-35.

Glascoe, F. P. (2003). How well do parents concerns identify children with behavioural and emotional problems? Clinical Pediatrics, 42(2) 133-138.

Gorinski, R. (2005). Pasific Islands school community parent liaison project case study. Wellington, New Zealand: Ministry of Education. Retrieved August 6, 2007, from http://educationcounts. edcentre.govt.nz/publications/ pasifika/piscplp.html

Guskey, T. R. (2002). Does it make a difference? Evaluating professional development. Educational Leadership, 59(6), 9-27.

Harvard Family Research Project. (2007). Family involvement makes a difference 2, Harvard Graduate School of Education. Retrieved April 16, 2007 from http://www.gse. harvard.edu/hfrp/content/projects/fine/resources/ research/elementary.pdf

Jones, C. (2006). Continuity of learning: Adding funds of knowledge from the home environment. set: Research Information for Teachers, 2, 28-31.

Ministry of Education. (1996). Te Whāriki: He Whāriki Marautanga mō ngā Mokopuna o Aotearoa: Early Childhood Curriculum. Wellington, New Zealand: Learning Media. 
Ministry of Education. (2004a). Kei Tua o te Pae Assessment for Learning: Early Childhood Exemplars. Wellington, New Zealand: Learning Media.

Ministry of Education. (2006). Educate: Statement of Intent 2006-2011. Retrieved April 12, 2007, from http://www. minedu.govt.nz/web/downloadable/dl11148_v1/ ministry-of-education-statement-of-intent-2006---2.pdf

Ministry of Health. (2007). Well Child. Retrieved July 3, 2007 from http://www.moh.govt.nz/moh.nsf/indexmh/wellchild-review-framework

Ministry of Social Development. (2007). Statement of Intent. Retrieved July 3, 2007 from http://www.msd.govt.nz/ publications/statement-of-intent/2007/children-andyoung-people.html

Mitchell, L. \& Cubey, P. (2003). Characteristics of professional development linked to enhanced pedagogy and children's learning in early childhood settings: Best evidence synthesis. Wellington, New Zealand: Ministry of Education.

Podmore, V. N. \& May, H. (with Mara, D., 1998). Evaluating early childhood programmes using the strands and goals of Te Whāriki, the national early childhood curriculum. Final report on phases one and two to the Ministry of Education. Wellington, New Zealand.

Podmore, V. (with May, H., 2003). "The child's questions": Narrative explorations of infants' experiences of Te Whaariki. Journal of Australian Research in Early Childhood Education, 10(1), 69-80.

Podmore, V., May, H., \& Carr, M. (2001). The "child's questions": Programme evaluation with Te Whāriki using "Teaching Stories. Early Childhood Folio, 5.

Pollard, A., \& James, M. (2006). The Teaching and Learning Research Programme (TLRP). New Zealand Council for Educational Research seminar, 4 December, Wellington.

Robertson, J. (2005). Ten principles for principled leadership practice of professional learning communities. Education Today, 6, 4-5.

Royal Tangaere, A. (1996). Māori human development learning theory. In B. Webber (Ed.), He paepae korero: Research perspectives in Māori education (pp. 109-122). Wellington, New Zealand: New Zealand Council for Educational Research.

Severson, H., Walker, H., Hope-Doolittle, J., Kratochwill, T., \& Gresham, F. (2007). Proactive, early screening to detect behaviourally at-risk students: Issues, approaches, emerging innovations, and professional practices. Journal of School Psychology, 45,137-161.

Sykora, J. (2005). Off to a better start: What we know about early intervention services. Social Policy Journal of New Zealand, 2, 117-130.
Walsh, K. (2006). The contested terrain of teachers detecting and reporting child abuse and neglect. Journal of Early Childhood Research, 4(1), 65-76.

Wenger, E. (1998). Communities of practice: Learning, meaning and identity. Cambridge: Cambridge University Press.

Wenger, E. (2002). Cultivating Communities of Practice. Boston: Harvard Business School Press.

Whitely, H., Smith, C. \& Hutchinson, J. (2005). Empowering early years workers to identify and target areas of difficulty in preschool children. Early Years, 25(2), 155-166.

Wilms, D. (Ed.). (2002). Vulnerable Children: Findings from the Canadian Longitudinal Study of Children and Youth. Edmonton: University of Alberta Press.

\section{ACKNOWLEDGEMENT}

We would like to acknowledge the support and positive involvement of the many project participants who contributed their time, energy and wisdom so willingly to Do You Know Me? E Mohio Ana Koe Ki Ahau? Our thanks go to you all.

Takanga 'etau fohe.

If we all pull together we will move forward.

Nāu te rourou, nāku te rourou, ka ora te iwi. Your food basket, and my food basket, will satisfy all.

\section{FURTHER INFORMATION}

Further information about Do You Know Me? E Mohio Ana Koe ki Ahau can be found on the Ministry of Education website www.minedu.govt.nz 


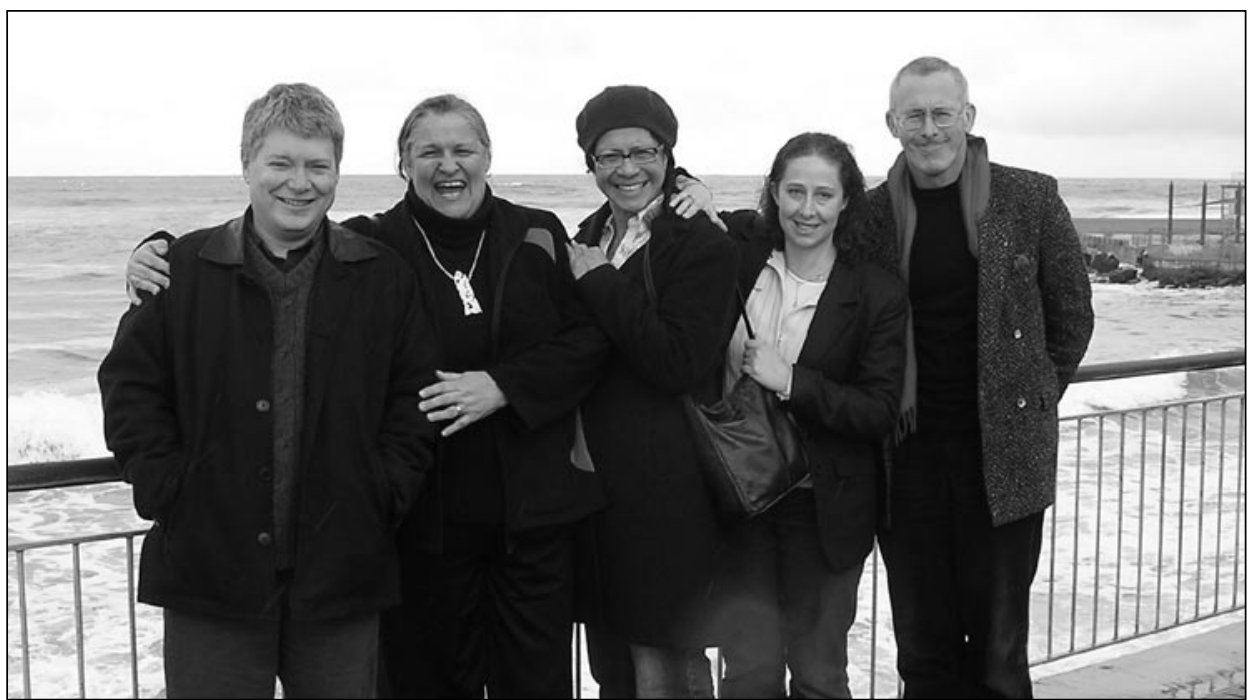

Bill Gilmore, Alison Tu'ionetoa, Esther Tavui, Vicky Haslam, Bruce Kent

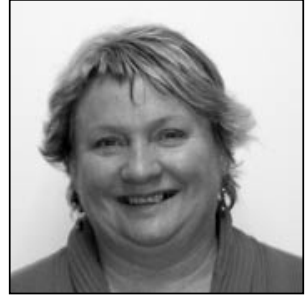

Margaret Crosswell

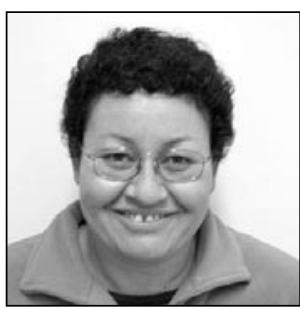

Raewyn Hitaua

\section{Bill Gilmore}

Bill Gilmore is a psychologist working with, Ministry of Education, Special Education in Otago, and in private practice for the Family Court. He has previously worked as a psychologist in Southland and as a primary teacher.

\section{Email}

bill.gilmore@minedu.govt.nz

\section{Vicky Haslam}

Vicky Haslam works for Ministry of Education, Special Education in the Waikato. She is currently a Service Manager in the school sector and previously worked in Gisborne as a Service Manager in Early Intervention. Vicky is a registered Speech-Language Therapist who trained at London University and practiced in the UK, Germany and Cyprus before moving to New Zealand in 2001.

\section{Email}

vicky.haslam@minedu.govt.nz

\section{Raewyn Hitaua}

Raewyn Hitaua is an Early Intervention Teacher working with Ministry of Education, Special Education in Gisborne. Raewyn has a keen interest in and passion for working collaboratively with Māori whānau, agencies, and communities, to improve and support educational and learning opportunities for all tamariki.

\section{Email}

raewyn.hitaua@minedu.govt.nz

\section{Bruce Kent}

Bruce Kent comes from a background as a teacher and an educational psychologist. Along the way he has also completed a PhD in Health Science. He has been a Senior Advisor, Professional Practice and the project manager for several national research projects including the one referred to in this article. He currently works for Ministry of Education, Special Education in Manukau.

\section{Email}

bruce.kent@minedu.govt.nz

\section{Esther Tavui}

Esther Tavui comes from a teaching background (regular and special education) and has been an Adviser on Deaf Children for Ministry of Education, Special Education. This work also involved her in the development and provision of services for Māori and Pasifika. She was involved in the Ministry of Education cochlear implant habilitation programme and has served as a NZEI representative.

\section{Alison Tu'ionetoa}

Alison Tu'ionetoa is a special education advisor working for Ministry of Education, Special Education in North-West Auckland. She has been a teacher at primary and secondary levels including eighteen years in schools in Tonga and five years working with at-risk and special needs secondary students in New Zealand. She is passionate about enabling schools and education services to work more collaboratively with Pasifika families and communities for better outcomes for their children.

\section{Email}

alison.tuionetoa@minedu.govt.nz

\section{Margaret Crosswell}

Margaret Crosswell works as an early intervention teacher for Ministry of Education, Special Education in Otago. She has an early childhood teaching background and has previously worked for IHC in Opotiki and CCS in Rotorua, She is currently an Incredible Years facilitator. She believes that user friendly resources for educators can assist parent involvement and lead to more responsive support for young children.

\section{Email}

margaret.crosswell@minedu.govt.nz 